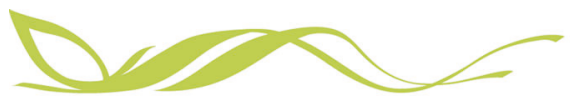

\title{
Author Correction: The radius of the umbrella cloud helps characterize large explosive volcanic eruptions
}

Robert Constantinescu, Aurelian Hopulele-Gligor, Charles B. Connor, Costanza Bonadonna (D), Laura J. Connor, Jan M. Lindsay, Sylvain Charbonnier \& Alain C. M. Volentik

Correction to: Communications Earth \& Environment https://doi.org/10.1038/s43247-020-00078-3, published online 4 January 2021.

The original version of this Article contained an error in the author affiliations. Aurelian Hopulele-Gligor was incorrectly associated with a personal address. This has now been corrected in both the PDF and HTML versions of the Article.

Published online: 25 January 2021

\footnotetext{
(c) (i) Open Access This article is licensed under a Creative Commons Attribution 4.0 International License, which permits use, sharing, adaptation, distribution and reproduction in any medium or format, as long as you give appropriate credit to the original author(s) and the source, provide a link to the Creative Commons license, and indicate if changes were made. The images or other third party material in this article are included in the article's Creative Commons license, unless indicated otherwise in a credit line to the material. If material is not included in the article's Creative Commons license and your intended use is not permitted by statutory regulation or exceeds the permitted use, you will need to obtain permission directly from the copyright holder. To view a copy of this license, visit http://creativecommons.org/licenses/by/4.0/.
}

() The Author(s) 2021 